\title{
Liquid crystal dispersions containing nanoparticles of different anisometry: carbon nanotubes and organomodified laponite
}

\author{
A.N.Samoilov ${ }^{1}$, S.S.Minenko ${ }^{1}$, L.N.Lisetski ${ }^{1}$, \\ E.A.Solovyova ${ }^{2}$, N.I.Lebovka ${ }^{2}$, M.V.Vistak ${ }^{3}$ \\ ${ }^{1}$ Institute for Scintillation Materials, STC"Institute for Single Crystals", \\ National Academy of Sciences of Ukraine, 60 Nauky Ave., 61001 Kharkiv, Ukraine \\ ${ }^{2}$ F.Ovcharenko Institute of Biocolloidal Chemistry, \\ National Academy of Sciences of Ukraine, 42 Vernadsky Prosp., 03142 Kyiv, Ukraine \\ ${ }^{3}$ Chair of Biophysics, Lviv National Medical University, \\ 69 Pekarska Str., 79000 Lviv, Ukraine
}

\section{Received March 14, 2017}

Optical transmission and optical microscopy studies have been carried out for dispersions of organomodified laponite in cholesteric liquid crystal (CLC) matrices. Laponite samples with different degree of exfoliation, obtained by different treatment procedures, were used, with laponite concentration in the dispersions varying from 0.05 to $0.4 \%$. The results obtained were compared to previously reported data on dispersions of carbon nanotubes in similar experimental conditions. As a general tendency, at low concentrations the nanoparticles tended to accumulate at the CLC texture defects, while at higher concentrations they became dispersed in the anisotropic liquid crystalline structure, with the degree of homogeneity and particle aggregation features depending upon specific features of each case.

Keywords: organomodified laponite, cholesteric liquid crystal, carbon nanotubes.

Проведены исследования методами оптического пропускания и оптической микроскопии для дисперсий органомодифицированного лапонита в холестерических жидкокристаллических (ХЖК) матрицах. Использованы образцы лапонита с различной степенью эксфолиации, полученные различными способами, при содержании лапонита в дисперсиях от $0,05 \%$ до $0,4 \%$. Проведено сопоставление результатов с ранее полученными данными по дисперсиям углеродных нанотрубок в аналогичных экспериментальных условиях. Общей тенденцией является стремление наночастиц при малых концентрациях располагаться на дефектах текстуры ХЖКК, тогда как при более высоких концентрациях они распределяются в анизотропной жидкокристаллической структуре. При этом степень гомогенности и характер агрегации частиц зависели от конкретных особенностей каждого случая.

Рідкокристалічні дисперсії, що містять наночастинки різної анізометрії: вуглецеві нанотрубки та органомодифікований лапоніт. О.М.Салойлов, С.С.Міненко, Л.М.Лисецький, О.О.Соловйова, М.І.Лебовка, М.В.Вісътак.

Проведено дослідження методами оптичного пропускання та оптичної мікроскопії для дисперсій органомодифікованого лапоніту у холестеричних рідкокристалічних (ХРК) матрицях. Використано зразки лапоніту з різним ступенем ексфоліації, отримані за різними методиками обробки, з концентраціями лапоніту у дисперсіях від $0,05 \%$ до 0,4\%. Проведено порівняння отриманих результатів з раніше одержаними даними для дисперсій вуглецевих нанотрубок в аналогічних експериментальних умо- 
вах. Як загальна тенденція, на малих концентраціях наночастинки збиралися на дефектах текстури ХРК, а при більших концентраціях вони розподілялися у анізотропній рідкокристалічній структурі, причому ступінь гомогенності та характер агрегації частинок залежали від конкретних умов кожного випадку.

\section{Introduction}

One of the promising classes of new composite nanomaterials are dispersions of various nanoparticles in liquid crystal (LC) matrices [1-4]. Among various types of nanoparticles used in such studies, great attention is attired by carbon nanotubes (CNT), which in many cases can improve the performance characteristics of LC materials or give rise to novel electrooptical or other practically significant effects [5-8]. Among the examples are disc- or plate-like particles of exfoliated montmorillonite (MMT) [9-11] or laponite (LPT) $[12,13]$. Since MMT and LPT are generally used in a chemically modified form, they are generally designated as "modified organoclays".

In our recent papers [14-16], we have shown that addition of dispersed CNTs to cholesteric liquid crystals (CLC) can lead to substantial changes in the textures of the matrix CLC samples, which is accompanied for essentially nonlinear variation of optical density with increased concentration of nanotubes. In particular, at low concentrations the introduced CNTs tend to locate themselves at structural defects of the planar cholesteric texture (e.g., at so-called "oily steaks"). When the concentration of CNTs is increased (to about $0.1 \%$ ), they tend to form aggregates of their own in the bulk of the cholesteric texture, and the initial oily steaks largely disappear. In the present work, we carried out similar optical density and optical microscopy studies of CLC with dispersed particles of laponite. An important question related to general problems of liquid crystal dispersions of nanoparticles was to clear up whether the effects of laponite on CLC texture would be similar or not to those of CNTs. Another question was to check eventual differences in behavior of different kinds of organomodified laponite.

\section{Materials and methods}

The photoactive nematic ZhK440 (a mixture of 4-n-butyl-4'-methoxyazoxybenzene + 4-n-butyl-4'-heptanoylazoxybenzene in 2:1 ratio) was obtained from NIOPIK, Russia, and additionally purified by column chromatography on silica gel using a mixture of petroleum ether and benzene as the eluent.
After evaporation of the solvent, the material was recrystallized from hexane at $20^{\circ} \mathrm{C}$. Nematic 5CB (4-n-pentyl-4'-cyanobiphenyl) of $99.5 \%$ purity was obtained from Chemical Reagents Plant, Ukraine. As a cholesteric component, we used a mixture of $30 \%$ cholesteryl formate, $5 \%$ cholesteryl butyrate and $65 \%$ cholesteryl nonanoate (mixture M5). The cholesterol esters were obtained from Chemical Re-agents Plant, Ukraine and used without further purification. Laponite RD (LPT) (Rockwood Additives Ltd., UK), which is a synthetic hectorite, is a swelling layered substance of 2:1 structural type with molecular formula $\mathrm{Na}_{0.7}\left[\left(\mathrm{Si}_{8} \mathrm{Mg}_{5.5} \mathrm{Li}_{0.4}\right) \mathrm{O}_{20}(\mathrm{OH})_{4}\right]$. In dry state it is a white powder, in which the disc-like particles are packed into stacks. The thickness and diameter of these discs are about $1 \mathrm{~nm}$ and 25-30 nm, respectively [17].

The platelets of original laponite were modified by ion-exchange reactions with the surfactant cetyl-trimethylammonium-bromide (CTAB, $\mathrm{C}_{16} \mathrm{H}_{33}-\mathrm{N}\left(\mathrm{CH}_{3}\right)_{3} \mathrm{Br}$, Fluka, Germany) with $99.5 \%$ purity. In aqueous suspension the surface coverage of laponite by adsorbed CTAB was anticipated. The details of the modification process will be published elsewhere.

The obtained suspensions were divided into two parts and stirred vigorously for $6 \mathrm{~h}$ at $T=293 \mathrm{~K}$ ("cold" sample) and $\mathrm{T}=$ $253 \mathrm{~K}$ ("hot" sample). After temperature incubation, the suspensions were filtered using a disc filter funnel and centrifuged. Finally, the obtained organo-laponite "cold" (LPT-c) and "hot" (LPT-h)) samples were freeze-dried (for $20 \mathrm{~h}$ ) for preservation of their dispersion ability in organic media. The LC+LPT dispersions within 0.01$0.36 \%$ LPT concentration range were obtained by adding the appropriate weights to the LC solvent in the isotropic state with subsequent 1-2 min sonication of the mixture using a UZD-22/44 ultrasonic disperser (Ukrrospribor, Sumy, Ukraine). As a LC matrix, we used a cholesteric mixture of $25 \%$ M5 and $75 \%$ 5CB. We chose a mixture of nematic and cholesterol esters, rather than an induced cholesteric composed of a nematic and a chiral dopant of similar structure. As it has been shown in [18], the presence of cholesterol esters suppresses un- 


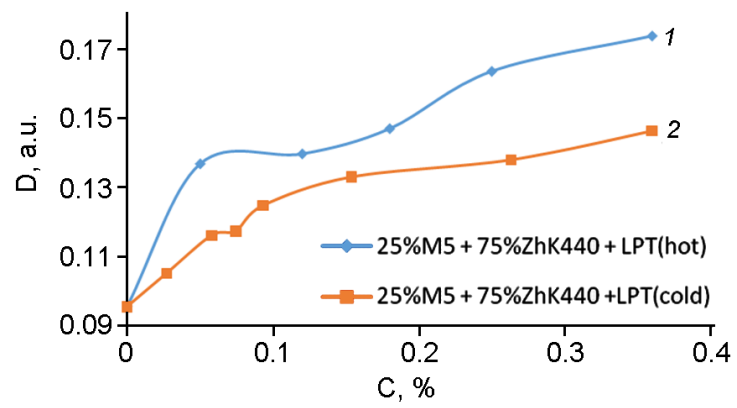

Fig. 1. Optical density $D\left(\right.$ at $20^{\circ} \mathrm{C}$ ) versus the concentration of LPT, CLPT, in the mixture $25 \% \mathrm{M} 5+75 \%$ ZhK440 at different type of LPT: 1 - $25 \%$ M5 + 75 \% $\mathrm{ZhK440+}$ LPT(hot), $2-25 \%$ M5 + $75 \%$ ZhK440 + LPT(cold).

controlled formation of large fractal aggregates of carbon nanotubes.

Optical transmission was measured using a Shimadzu UV-2450 spectrophotometer (Japan) within 190-1100 nm spectral range. Sandwich-type LC cells (20 $\mu \mathrm{m}$ thickness) were used. The cell walls were treated with polyvinyl alcohol water solution and, after drying, rubbed in one direction to obtain the planar texture. The LC+LPT dispersions were introduced between the cell walls using the capillary forces at the temperatures above the transition to the isotropic phase. The measurements were carried out at $20^{\circ} \mathrm{C}$, with temperature stabilization by a flowing-water thermostat $\left( \pm 0.1^{\circ} \mathrm{C}\right)$. The values of optical transmission were determined at $800 \mathrm{~nm}$, considered to be sufficiently far from any bands of selective reflection or absorption of the liquid crystalline host. The optical transmission $T_{r}$ was re-calculated to optical density $D$ in the same way as in our previous papers $[15,16]$ as $\mathrm{D}=-\log \left(T_{r} / 100\right)$. Optical microphotographs of the studied LC+LPT suspensions in a sandwich-type LC cells were obtained using a Micromed POLAR 3 microscope (Saint Petersburg, Russia) equipped with a digital camera.

\section{Results and discussion}

Fig. 1 shows optical density as function of LPT(hot) and LPT(cold) concentration in the LC matrix consisting of $25 \%$ M5 and $75 \%$ ZhK440. The obtained dependences indicate that the matrices containing LPT(hot) have higher optical density than matrices with LPT(cold). At the same time, the optical transmission spectra (C3Fig. 2) were virtually identical for both LPT types. The addition of LPT shifted the selective

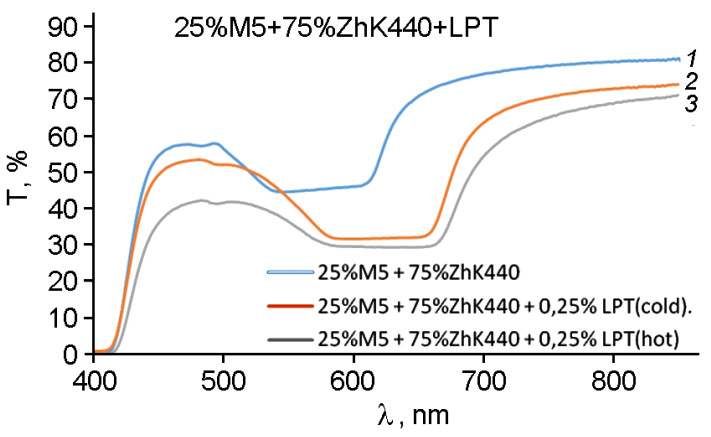

Fig. 2. Selective reflection peaks (at $20^{\circ} \mathrm{C}$ ) of system $25 \%$ M5 + $75 \%$ ZhK440 + LPT: 1 $-25 \% \mathrm{M} 5+75 \%$ ZhK440, $2-25 \%$ M5 $+75 \% \quad$ ZhK440 + $0.25 \%$ LPT(cold), 3 $25 \% \quad \mathrm{M} 5+75 \quad \% \quad \mathrm{ZhK} 440+0.25 \quad \%$ LPT(hot).

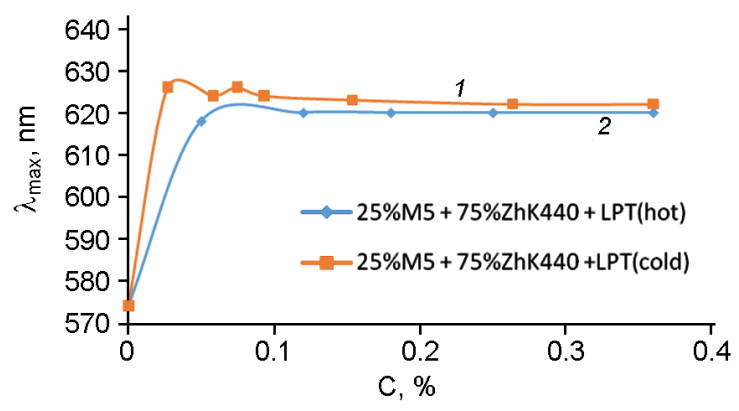

Fig. 3. Wavelength of maximum selective reflection $\lambda_{\max }$ (at $20^{\circ} \mathrm{C}$ ) as function of LPT concentration for the system $25 \% \mathrm{M} 5+$ $75 \%$ ZhK440: 1 - $25 \%$ M5 $+75 \%$ ZhK440 + LPT(cold), $2-25 \% \mathrm{M} 5+75 \%$ ZhK440 + LPT(hot).

reflection peaks by the same amount after reaching the concentration of $\sim 0.02 \%$ (LPT-h) and $\sim 0.05 \%$ (LPT-c), with practically no changes after further increase in LPT concentration (Fig. 3). The mechanism of the observed differences in the behavior of the cholesteric mixtures M5 + ZhK440 in the presence of LPT-h and LPT-c can be better understood from analysis of the microstructure of these composites. Fig. 4 and Fig. 5 present examples of the microscopic images of the cholesteric mixture M5 + ZhK440 at different concentrations of LPT ("hot", Fig. 4) and LPT(cold, Fig. 5). In the cholesteric phase, we can observe typical networks of oriented topological defects (socalled oily streaks). For dispersions of LPT-h, we could note evidence of the presence of strong interaction of LPT dispersed particles with oily streaks and their preferential localization at the topological defects. It is in agreement with previously reported observations that topological defects could be efficient traps for different types of 


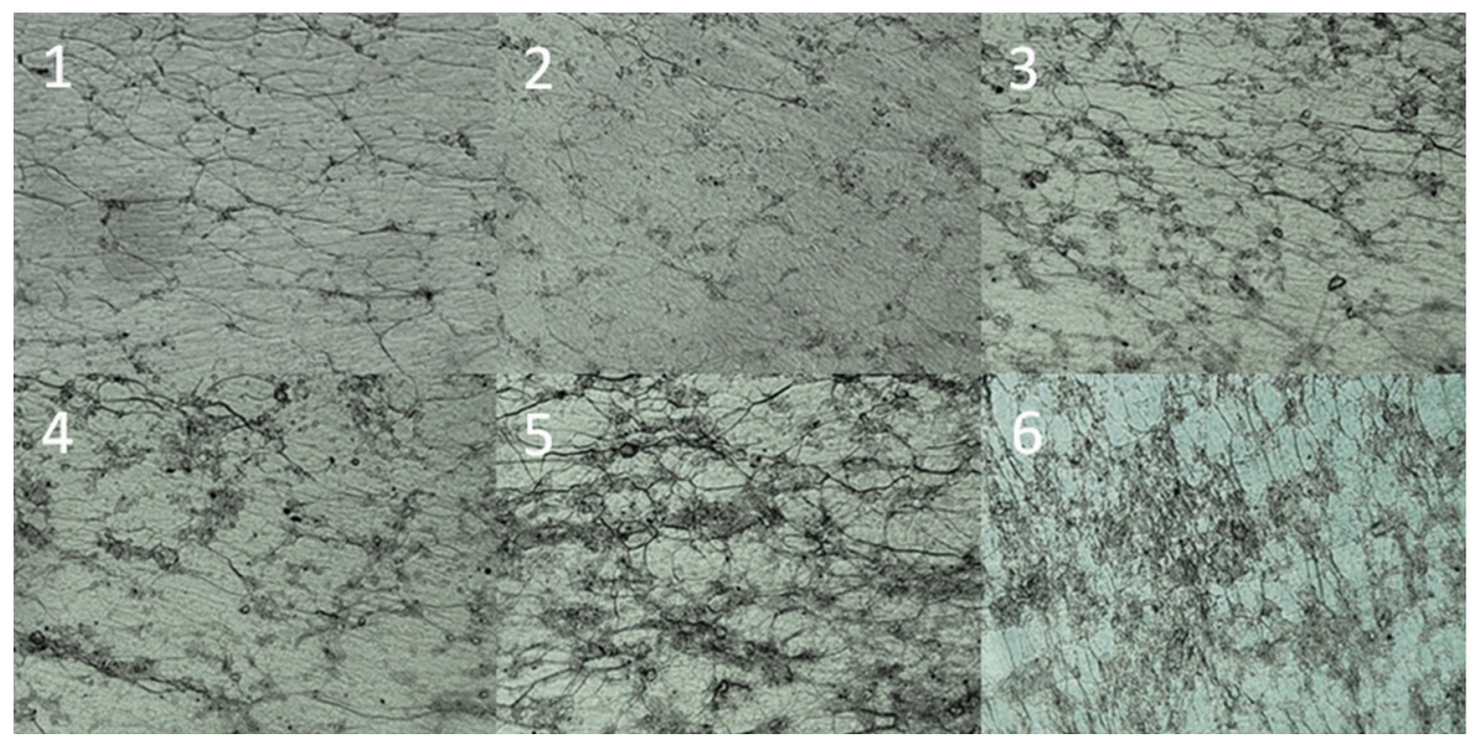

Fig. 4. Examples of the microscopic images of the cholesteric mixture $25 \% \mathrm{M} 5+75 \%$ ZhK440 at different concentration of LPT(hot): $1-25 \% \mathrm{M} 5+75 \%$ ZhK440 + $0.05 \%$ LPT(hot), $2-25 \%$ M5 + 75 \% ZhK440 + 0,09 \% LPT(hot), $3-25 \%$ M5 + $75 \%$ ZhK440 + $0.12 \%$ LPT(hot), $4-$ $25 \% \mathrm{M} 5+75 \%$ ZhK440 + $0.18 \%$ LPT(hot), $5-25 \%$ M5 $+75 \%$ ZhK440 + $0.25 \%$ LPT(hot), $6-25 \% \mathrm{M} 5+75 \%$ ZhK440 + $0.36 \%$ LPT(hot).

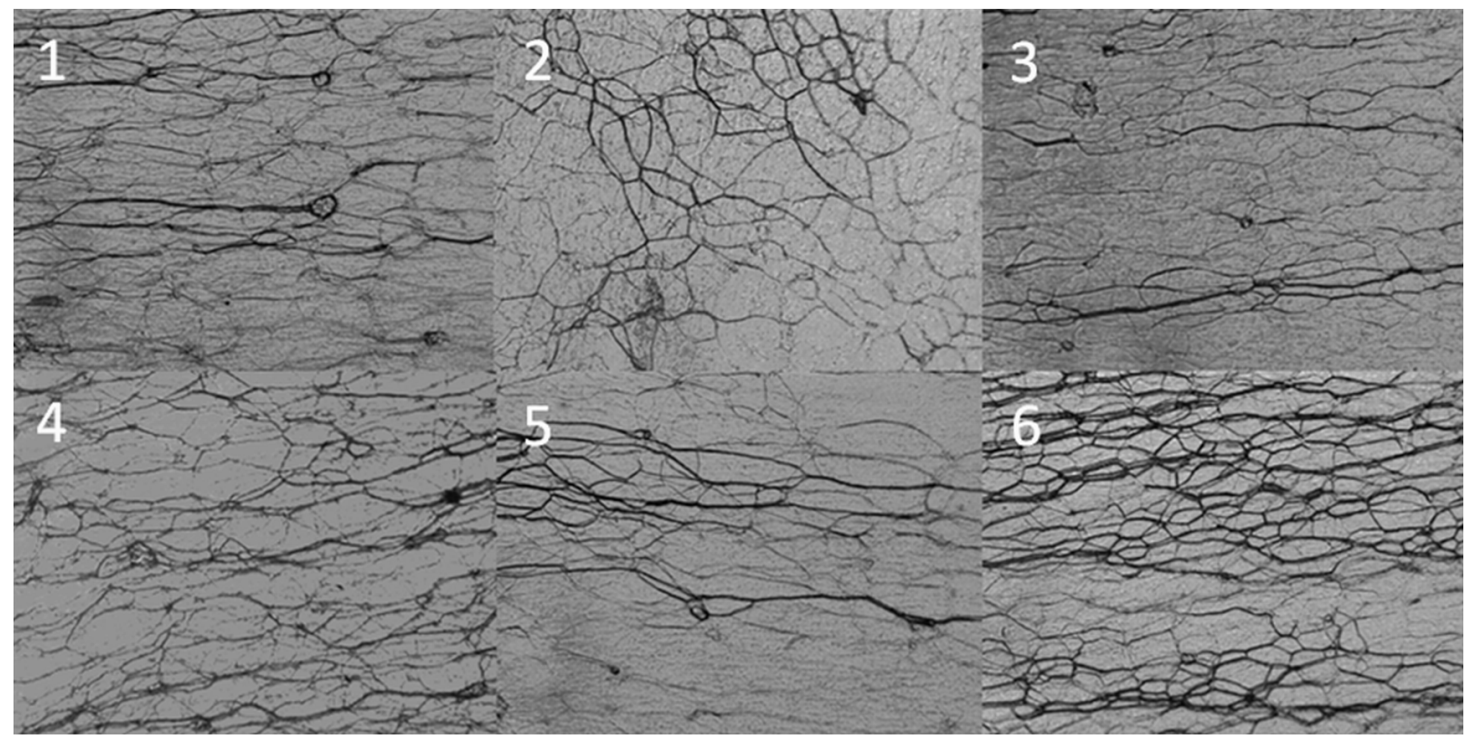

Fig. 5. Examples of the microscopic images of the cholesteric mixture $25 \%$ M5 $+75 \%$ ZhK440 at different concentration of LPT(cold): $1-25 \%$ M5 $+75 \%$ ZhK440 + $0.05 \%$ LPT(cold), $2-$ $25 \% \quad \mathrm{M} 5+75 \quad \% \quad$ ZhK440 + $0.09 \%$ LPT(cold), $3-25 \%$ M5 $+75 \%$ ZhK440 $+0.12 \%$ LPT(cold), $4-25 \%$ M5 + $75 \%$ ZhK440 + $0.18 \%$ LPT(cold), $5-25 \%$ M5 + $75 \%$ ZhK440 + $0.25 \%$ LPT(cold), $6-25 \% \mathrm{M} 5+75 \%$ ZhK440 + $0.36 \%$ LPT(cold).

nanoparticles [19-22]. However, for LPT-c, the picture was substantially different (Fig. 5) - LPT particles seemed to be uniformly distributed throughout the entire matrix.

The observed behavior could be explained by different degree of exfoliation obtained with LPT-h and LPT-c samples. The apparently homogeneous distribution of LPT-c (Fig. 5) reflected higher degree of exfolia- tion, with much smaller effects on the cholesteric texture as compared with LPT-h. If we compare the obtained data with earlier results on carbon nanotube dispersions obtained in similar experimental conditions $[15,16]$, we can see that with "hot" LPT, the optical density vs.LPT concentration plots show signs of non-monotonous behavior similar to that in CLC+CNT systems 
(Fig. 1, curve 1), while this dependence becomes somewhat closer to the Bouger-Lambert-Beer linearity (Fig. 1, curve 2).

\section{Conclusion}

To conclude, we can claim that joint application of the proposed set of relatively simple experimental methods (optical transmission + optical microscopy) can provide substantial information on the arrangement of micro/nano particles of different annisometry in liquid crystal dispersions.

\section{References}

1. M.Urbanski, J.P.F.Lagerwall, J.Mater.Chem. C., 4, 3485 (2016).

2. M.F.Prodanov, O.G.Buluy, E.V.Popova et al., Soft Matter, 12, 6601 (2016).

3. P.-C.Wu, L.N.Lisetski, W.Lee, Opt Express, 23, 11195 (2015).

4. Y.Garbovskiy, Appl.Phys. Lett., 110, 041103 (2017).

5. M.Rahman, W.Lee, J.Phys. D:Appl.Phys., 42, 063001 (2009).

6. L.Lisetski, M.Soskin, N.Lebovka, in: Physics of Liquid Matter: Modern Problems, Chapter 10, Springer Proc. in Physics, v.171, Springer Int.Publ., Switzerland (2015), p.243.

7. S.P.Yadav, S.Singh, Progr.Mater.Sci., 80, 38 (2016).

8. S.Schymura, J.H.Park, I.Dierking, G.Scalia, in: Liquid Crystals with Nano- and Micropar- ticles, ed. by J.P.F.Lagerwall, G.Scalia, World Scientific, Singapore (2017), p.603.

9. S.S.Minenko, A.I.Kocherzhyn, L.N.Lisetski, N.I.Lebovka, Functional Materials, 16, 319 (2009).

10. A.M.Chepikov, S.S.Minenko, L.N.Lisetski et al., Functional Materials, 19, 343 (2012).

11. S.S.Minenko, M.I.Lebovka, L.M.Lysetskyi, Patent of Ukraine 102723, (2013).

12. O.Yaroshchuk, S.Tomylko, O.Kovalchuk, N.Lebovka, Carbon, 68, 389 (2014).

13. M.Lavric, V.Tzitzios, G.Cordoyiannis et al., Mol. Cryst. Liq. Cryst., 615, 14 (2015).

14. A.N.Samoilov, S.S.Minenko, L.N.Lisetski et al., Functional Materials, 21, 373 (2014).

15. L.N.Lisetski, S.S.Minenko, A.N.Samoilov, N.I.Lebovka, J. Mol. Liq., 235, 90 (2017).

16. A.N.Samoilov, L.N.Lisetski, M.S.Soskin et al., Liq.Cryst., DOI:10.1080/02678292.2017 1314560 (2017).

17. R.G.Avery, J.D.F.Ramsay, J.Coll. Interface Sci., 109, 448 (1986).

18. N.I.Lebovka, L.N.Lisetski, M.I.Nesterenko et al., Liq. Cryst., 40, 968 (2013).

19. H.Yoshida, Y.Tanaka, K.Kawamoto et al., Appl.Phys. Express, 2, 121501 (2009).

20. E.Karatairi, B.Rozic, Z.Kutnjak et al., Phys. Rev. E, 81, 41703 (2010)..

21. D.Coursault, J.Grand, B.Zappone et al., Adv. Mater., 24, 1461 (2012).

22. D.Coursault, B.Zappone, A.Coati et al., Soft Matter, 12, 678 (2016). 